\title{
Dance as Aggressiveness
}

The woman who founded Tenshō-kōtai-jingū-kyō, Kitamura Sayo (19001967), publicly announced in July 1945 that the world was coming to an end and that she had been chosen by the absolute deity Tensho Kotai Jingu to be the savior of the world. People began to gather to her banner, a religious organization was formed, and legal incorporation of the group as a religious juridical person took place in January 1947. Teaching that regret, desire, hatred, love and other emotional antipathies were the cause of all misfortune, the founder urged people to free themselves of such restraints by praying earnestly until they attained a state in which the self was completely forgotten. Since the members of the group perform a ritual dance and fall into an ecstatic condition at the group meetings, the movement is called the Dancing Religion (Matsuno 1972: 230).

Kitamura Sayo, or Ōgamisama, was born in the South-West of Japan, in the Yamaguchi prefecture. She was a farmer's wife, worked hard in the fields and never got enough sleep. In July 1942 a barn on the Kitamura family was burnt down and Sayo saw herself as the cause of the accident. Serving the kami of the ancestors had for her been the first thing in life, so she was deeply disturbed by the fire. She blamed herself for having destroyed the ancestor's property and disturbing the neighbours. After praying and praying for forgiveness, she still suffered torments of conscience day after day. She went to a well-known healer in a nearby village, who gave her an explanation (the fire was caused by a jealous arsonist) and some advice for the future. In her diary two days later, and thirteen days later, we can read, "Got up at $2.00 \mathrm{a}$. $\mathrm{m}$. and took cold bath of penance and prayed... each time I take a cold bath of penance, I feel as if My body and soul have been purified and that I have come nearer to God. My mind is filled only with the eagerness of praying to purify Myself and I have no worldly cares" (Tensho-kotai-jingu-kyo 1954: 15).

In March 1944 the healer living nearby had a divine message for Kitamura Sayo: "All the Angels of Heaven and Earth will descend upon You and You will become a living God on earth." (Tensho-kotai-jingu-kyo 1954: 16). After that she began to receive inspiration from an "almighty kami" 
and she became the mouthpiece of the deity who possessed her. What the entity inside commanded her to say always flabbergasted people and was often taken as a sign of madness or insanity. She could not act in accordance with her own intentions but had involuntarily to obey the dictates of the one in her body. Otherwise she got headaches, stomach pains and suffered attacks of diarrhea.

According to Kitamura Sayo's life history, what started with animal spirit possession, which is quite common in the area, became something else when the snake spirit transformed itself into two beings, that of Kotaijin (a kami connected to the Ise shrines) and Amaterasu (the Sun goddess, here as Tensho, meaning heavenly) who united in the body of the selected woman as "The Almighty God of Heaven".

In the middle of autumn 1944 she was led by the divinity inside her to a mountain on her property at $02.00 \mathrm{a} . \mathrm{m}$. Kitamura Sayo rode her bicycle to the foot of the mountain, about two miles from her house, and climbed the hill. At the top she commenced a prayer that was given to her as the only prayer in accordance with God's will: NA-MYO-HO-REN-GE-KYO.'

"Her prayer 'Na-myo-ho-ren-ge-kyo', sometimes drawn out and sometimes brief, was chanted with natural rhythm and reverberated among the surrounding mountains. When she finished praying, She lay on the ground, face upward, and watched the dawn breaking. After a pause, She resumed Her prayer. Once celestial lotus flowers in full bloom showered down from Heaven as the reddish sun ascended amongst the blossoms. Angels in full costume were dancing before Her... this is a dance of Angels, the One in Her body said. While She was watching the dance in admiration, She was in a celestial bliss and felt as if She had also become a dancing Angel" (Tensho-kotai-jingu-kyo 1954: 29-30).

In July 1945 Kitamura Sayo gave her first public sermon and her religious group was called Odori-sh $\bar{u} k y \bar{o}$, the Dancing Religion. The dance was something given to the foundress as a way to restore peace. "You have been appointed to perform a Salvation Dance when the present world is on the verge of collapse", the divinity inside Kitamura Sayo told her (Tenshokotai-jingu-kyo 1954: 46).

\footnotetext{
${ }^{1}$ Before 1964 Tenshō-kōtai-jingū-kyō used the same kanji as the Nichiren sect to indicate namu-myōho-renge-kȳ, but ceased doing so as a consequence of a lawsuit initiated by the Nishiren Shōshū. Inside the Dancing Religion the formula has been interpreted as "A woman with a little name has contacted the law of Heaven binding it into a teaching". Nowadays the members are instructed that the words are untranslatable, reflecting in their sounds a transforming influence of evil or negative unredeemed spirits. Kerner 1979: 317.
} 
To her followers Ōgamisama said, "I will establish true peace on this earth... World peace advocated by politicians is nothing but a camouflage of national interest based on selfishness... Peace can be brought only by practicing God's teaching" (Tensho-kotai-jingu-kyo 1960: 1-2).

The foundress of the Dancing Religion danced with the Almighty God that struck in Hiroshima in 1945, allied with the enemy. "The other name for MacArthur is the 'Messenger of Divinity'. He was sent to Japan as an agent of the Divine Wind... The members of the Diet were high-handed criminals, and the Cabinet Ministers were even worse. Who put them in jail? Nobody but MacArthur-Is this not the work of a good Divine Wind?" (Tensho-kotai-jingu-kyo 1954: 60-61).

When the Japanese emperor denied being divine in his New Year speech, on the first of January 1946, the first year of God's Kingdom began, according to Kitamura Sayo. The sun-goddess Amaterasu was a part of her and the heavenly god would now expand the spiritual world instead of the Japanese territory. As Kitamura Sayo established the foundation of God's Kingdom within Japan, she followed her Almighty God's command and designated Hawai'i as "the Bridge to the World".

\section{Hawai'i}

The situation among Japanese Americans in post-war Hawai'i was that $i$ ssei (the immigrants) were enemy, but nisei (second generation) were American citizens. "This often meant changed parent-child roles and the loss of parental authority over children... [since] Issei accepted from the beginning the role of their children as American citizens" (Kimura 1992: 226).

In Hawai'i, after the war, it was very important for the American Japanese to be Americans only - to identify with the other, the hostile one that used to be a friend. Issei, the immigrants, were enemy aliens, and therefore enemies in American eyes, and since public use of the Japanese language was forbidden, it was the interpretations, made by their children, of regulations concerning enemy aliens that issei had to depend on. In contrast to traditional customs, some had to substitute I-neither-saw-nor-heard for helpfulness. The "arrest of almost all the Issei leaders and the closing of all the Japanese instituitions stopped the functioning of their society, making the Issei the most desolate and isolated element of the island population. The freezing of Japanese assets, including bank accounts, and the loss of 
livelihood due to wartime regulations added to the atmosphere of insecurity" (Kimura 1992: 225).

The immigrants tried to eliminate everything Japanese. Cultural objects, as well as letters, books, photographs and Japanese flags were burnt. Issei and their children made great efforts to be identified with the United States; together with American flags they placed portraits of George Washington, Abraham Lincoln, and President Roosevelt in their homes. "The Issei chose these American figures as legitimate representations of America with the symbolic value of protection" (Kimura 1992: 225).

After the war, Kitamura Sayo arrived in Hawai'i to teach those who would become her followers what otherness was. She gave sermons and talked about the Almighty God who expanded his kingdom thanks to her, the Great Goddess, in command of lost human beings who would dance for world peace.

Kitamura Sayo identified with the enemy when Japan was invaded. To escape the anxiety stemming from the presence of a threatening authority, the so-called Caucasians, many Japanese in Hawai'i did the same thing. Sometimes the need for strength results in identification with the authoritarian for the purpose of neutralizing the threatening presence (cf. Moloney 1954: 116).

On October 12, 1952, Ögamisama made a trip around the island of Oahu and danced in ecstasy in public places, like parks and at religious sights (Tensho-kotai-jingu-kyo 1954: 180). The dance, muga-no-mai, surrendering and conquering, was used to proselytize, symbolizing the union of man and God. This dance was very offensive among the male converts after the war; it was performed in a way that reminded the spectators of military marches. According to members of the Dancing Religion who were converted when Ōgamisama made her first missionary tour, the more people that surrounded them when they were dancing in a public park, the more strongly the converts became convinced they were powerful servants of God. In compliance with the teaching of the Dancing Religion, to prosetylize spectators is to spread peace in the world, and this was extremely important after the war.

In Hawai'i, the Japanese as a group went down in the social scale and there was a huge change within the group itself, when it comes to status. What usually happens in societies in dangerous situations is that the authority of elders over juniors is stressed. This was inverted in Hawai'i after the Pearl Harbor attack. It is interesting to read the letters sent by isse $i$ that were put in internment camps. They tell their wives to look upon themselves as mothers of American citizens, and they instruct their sons to 
conduct themselves as loyal Americans and never let their fathers' situation affect the duties they have to "their native land". Many of them excuse themselves for being internees, afraid that their children will feel humiliated. On the path to assimilation the private aspects of ethnicity can be turned upside down, as in this case. That is because those aspects remain just as long as the group wants them. Under the pressure from an overarching majority some ethnic content might be lost or altered, but it should not be seen as some blind turning away from the roots. Nisei desired change therefore the process of Americanisation came from within sponsored by the ethnic group itself. "The general implication here is that 'deethnicisation' occurs because of the formidable attraction of mainstream life" (Edwards 1989: 180).

What comes from the inside because of lust for something new, and what comes from necessity for this other, is retrospectively always hard to tell. The extreme expression of the combination of Japanese morality and loyality to America was found in the combat teams composed of second generation Japanese in Hawai'i who volunteered during World War II. "Local Japanese attained the unprecedented ethnic glory through their heroic commitment to the American cause; their ethnic pride reached a peak paradoxically when the whole Japanese community was suddenly 'deJapanized' and the authority of Issei was downgraded to a nonentity" (Lebra 1972: 10). Ethnicity was not the only basis for Japanese group formation; nationality was also important. Nationality involves a wider range than ethnicity and when Kitamura Sayo arrived, she told the people who gathered around her that Japan was divine and the real war began when she became the mouthpiece of the sun-goddess Amaterasu; therefore Japan did not really lose the war. Kitamura Sayo alluded to the former expansion of the Japanese empire when she preached about the expansion of God's kingdom on earth. Her sermons were usually nothing but scoldings. The converts were chartised. Kitamura Sayo was often frantic with anger and accused her followers of not polishing their souls enough. In an ecstatic way she screamed about political leaders and priests, and she blamed the men in high positions for being "maggots". The voice of God inside her made her shout.

"I think, that we are concerned here with a widespread use of spiritpossession, by means of which women and other depressed categories exert mystical pressures on their superiors in circumstances of deprivation and frustration when few other sanctions are available to them" (Lewis 1989: 39). To Ōgamisama aggressiveness was a drama set up by her, the dancing goddess, as a way to win converts. It became a taken-for-granted human 
predisposition. "That which society defines, recognizes and problematizes as aggression may well be a set of functional activities dressed up as a cultural drama" (Rogers et al. 1995: 166).

\section{The Situation at the Time for the Founding of the Dancing Religion}

Kitamura Sayo, with bomber-planes around her in Japan, danced with angels for world peace. She left her ordinary self to escape the terrible world and to be with God. It was the God of the winners who once gave birth to Buddha, Jesus, and then to Ōgamisama. Through dancing a dance born in a wish to escape reality she was one with God's liberators, the Americans. She sang:

Oh, bring on the bombs - bring on the bombs -

May they exterminate the maggots of this rotten world,

And burn all their lairs to ashes, whereupon

Let there appear God's New Kingdom.

(Tensho-kotai-jingu-kyo 1954: 35).

The voice inside told her she should burn down the Imperial Palace, only leaving one wing. It would not be disrespectful, since the emperor had forsaken the nation. According to the one inside, Japan was founded upon the union of three things: the national domain, Tenshō-kōtai-jingū-kyō, and the emperor as the guardian of the nation. The voice said, "I have descended into Your body, and therefore equip yourself with the necessary knowledge to meet the situation. Even if the Emperor and Empress took cold baths of penance for three years, I would never descend into such defiled bodies as theirs... perform a Salvation Dance... they have failed to govern their country properly" (Tensho-kotai-jingu-kyo 1954: 46). After MacArthur's victory many male converts danced for peace in a very intense military marchlike way. "Dance is... an active creation of meanings, that is, social action dependent upon social relationships at the time" (Brinson 1988: 211).

The Japanese nation as a social institution fostered violence in a variety of ways during the war. Institutions can produce a weakened sense of personal responsibility for aggressive actions, and they can also dehumanize the victims of aggression. As an example, Japanese officers degraded the victims of South-East Asia through making them seem as if they were less than human. Features of a situation that lead to a disinhibition of aggression through deindividuation can be anonymity, loss of sense of responsibility, physiological arousal and intense sensory stimulation (Sabini 1992: 
513). When Kitamura Sayo gave her sermons, both in Japan and in Hawai'i, she put herself aside and acted as an aggressive doomster. Her act showed physical arousal and in many ways her performance was a case of deindividuation.

The moral code all Japanese share is one inhibition against expressing aggression and thereby harming others. As children they are taught not to be aggressive and offensive. But punishing someone for aggression can have a paradoxical effect. Watching other people being aggressive may lead to the disinhibition of aggression. Kitamura Sayo, maltreated by her mother-in-law, who functioned as an arbitrator in the marriage between Sayo and her husband, might in some ways have acted as a punished child. When you punish a child to inhibit the behaviour for which the child was punished, the punishment can have another effect, it might provide a model of aggression that encourages aggression. Kitamura Sayo's motherin-law used arbitrary power, she disciplined Sayo without explaining the reasons for that discipline. The old lady taught her daughter-in-law "that acting in a hostile way was an appropriate way to get what one wants (through modeling)" (cf. Sabini 1992: 506). During all the years with her really mean tyrant Sayo got more and more aggressive. But "aggression needs to be understood within the manifold of sets of meanings whereby aggression is constituted... not as an action or a state but as a set of interwoven textual identities, actions and descriptions" (Rogers et al. 1995: 169).

Kitamura Sayo was a frustrated woman, though with well-developed self-defence mechanisms, and became more and more offensive instead of defensive. It is that the dance became something like a cathartic activity I find interesting. In the middle of the night Sayo rode her bicycle long distances, upset and physiologically aroused she prayed and danced. Aroused she "used up" her aggression through intense dance, a process of catharsis. But did the opportunities to discharge her aggressions actually reduce it? According to several research results it seems to work the other way (see Buss 1966; Loew 1967) In her sermons Kitamura Sayo is usually more aggressive after the dance than before. The dance can be seen as a safe outlet for aggressive energy, as cathartic activity it releases the plug and allows aggressive energy to be released, but she is as mad, or even more, after than before.

Of course the word "aggression" means several very different things, and I use the same word for different forms, but it is all about aggression as a combination of influences. "We need also to address the problem that ag- 
gression is simply not accessible to empirical investigation other than as a set of socially negotiated meanings" (Rogers et al. 1995: 170).

Kitamura Sayo acted aggressively and found she was reinforced in some way, by getting what she wanted. She was therefore more likely to act in that way again. She gained power and social status through her aggressiveness. During war many people are rewarded for acting aggressively, and other people learn through vicarious reinforcement to imitate those that succeed. However, for anger to be converted to aggression, certain cues must be available in the environment. It seems like cues acts as triggers to aggression and aggression plus frustration creates anger, then anger together with the cue to act out cause aggressive behaviour (Rogers et al. 1995: 170).

The leader of the Dancing Religion pestered all other religious movements and molested their leaders. According to the dancing goddess, those who did not follow her teaching, Mioshie, would fall into hell. The salvation of the world should be carried out at all costs, and Ōgamisama "mobilized" her followers to attain world peace (Ogamisama's Sermon 1986: 6).

Kitamura Sayo worked hard and was always aroused when she shouted in front of people during her sermons. It seems that she could not relieve her arousal through the dance, she often became frustrated with what she saw and with the people she confronted, a frustration that enhanced aggression. She had very high blood pressure, usually around 230-240. One interpretation of the enhancement of aggression by extraneous arousal gives drive a direct role. According to this interpretation, extraneous arousal 'energizes' behaviour; it makes one do whatever one happens to be doing more intensely. Kitamura Sayo was a doomwatcher and her fire-andbrimstone sermons were intensified through her dance. Aggression and the transfer of arousal are important elements when the dance is seen as instrumental offensive power.

Because of the socio-cultural background in the specific war/post-war situation there was a militancy among the male converts in the peace dance. The members took a militant stand toward the outside society and Ogamisama told them to "defend vigilantly and to expand aggressively the Kingdom of God" (Lebra 1967: 69). Since one of the major factors to be taken into account when interpreting the dance "is the range and type of human movement, expression and communication used by the people from whom the particular dance emerges, for this determines, in part, the meaning of the dance" (Hodgens 1988: 65), we have to look at the breakdown in Japanese society in the 1930s, from Taisho democracy to triumphant militarism. 
Ōgamisama acted like a military, in a very unfeminine way, after she had been possessed by Tenshō-kōtai-jingū-kyō. She reflected Japan.

Ōgamisama made a political association with emperorship and thereby she made an accomodation to the world. The paradoxical militarism in the peace-dance was nurtured by male issei in Hawai'i. When they were studied in a park, it was noticed that they were waving their arms downward left and right, as in a march, and when it came to the melodies that were sung, "some are reminiscent of the songs taught in Japanese grade schools, of military marching songs" (Lebra 1967: 116).

The dance performed by some of the members of the Dancing Religion was a way to manifest Japanese features important at that time, a kind of imperialism. Historically the United States had provided demonstrations of imperialist methods, and as a means of self-preservation Japan identified herself with her enemy. The history of the United States and Japan in Hawai'i demonstrates the Japanese imitation of American methods.

After Perry effectively opened the doors of Japan, the actions of the American Marines were often copied by the Japanese. The emigration from Japan to Hawai'i, initially permitted by the Hawaiian king Kalakaua, grew enormous and justified an interest in the Hawaiian Islands. The manner in which the Japanese emissary aproached Hawai'i was patterned after Perry's "visit" to Japan. The dignitaries came in a ship of war, and in the same fashion as Perry had made his demands to Japan, they asked for the ichi bun (chief/headman). In 1898 the United States negotiated with the Hawaiians over the treaty of annexation. They reassured the Japanese officials that they had no such plans as a transfer of the islands to the United States. The Japanese were deceived and remembered this. On the $7^{\text {th }}$ of December, 1941, the Japanese emissaries in Washington talked of peace and called the idea of war ridiculous (Moloney 1954: 124).

Through out history it seems that the rulers of Japan have often identified with the enemy, and then the enemy has not been the other but the self. The dance of Ōgamisama was to some extent that of Christian angels. The Other was in form the God of the other, and the issei members tried to leave their selves for The Other (in muga-no-mai) and the other (in the acculturation process). Ogamisama told her followers to stand up and dance, and tried to explain that "I danced a similar dance in 1945 by the order of God in My body. The dance you just saw is an Angels' dance which you have seen in pictures or heard about in stories. If a person enters a state of non-ego, God will guide him to dance. Soon everyone of you will be able to perform this celestial dance (Tensho-kotai-jingu-kyo 1954: 68). Communion was a gathering of members who wished to get rid of the "me" 
through the "ego-less" dance. But it was also a spiritual march towards the Kingdom of God, and the dance was a piece of a strenuous life, a struggle in itself, striving for harmony through a release of tensions, aiming at Utopia and a society in which they all, sick and poor and filled with guilt, would be happy and healthy, free from frustration and anger. The dance was a war against the lack of peace.

For issei with hazy, undefined identities and a relaxation of discipline inside the families, to submerge in a group in a way that gave a new identity, partly through deindividuation, seemed attractive. To be lost in a group and there find a deified part of the self, in the search for a better me, was to the converts an exciting and self-confidence-lifting experience that made them polish their souls on the order of Ogamisama.

Inside the religious group issei could "steal back" the position they lost in Hawaiian society after the war. The rigid conformity juxtaposed with flexibility, the authority of $i$ ssei over nisei, was kept when the teachings of Ogamisama were put into practice. They placed themselves between the categories of ordinary social life and the classifications on which the order in post-war Hawai'i depended was annulled inside the Dancing Religion. Perhaps, the dance can be seen as one of those symbols that "designate temporary antinomic liberation from behavioral norms and cognitive rules (Turner 1990: 273).

What happened in Hawai'i after the war among those Japanese immigrants and their children that became members of the Dancing Religion was that frustration and aggression were taken care of. Acculturation anxiety was in many cases reduced thanks to the "religious family", the sect. Different processes which underlie social conformity, like identification, compliance, and internalization, should in this case not be seen as different but overlapping. The Japanese in Hawai'i, as a group, changed their attitudes in order to become more like the Americans they respected and admired after the Second World War. That could be called identification with the enemy. When it comes to compliance, subjects go along with the majority but do not change their private beliefs, including traditional customs. The group as a whole identified with the Americans, the so-called haole, or white ones. Inside the group, the issei were directly related to the fact that the majority had power on its side, because of the war situation, which it could use through sanctions. Compliance is when a majority influences a minority. But in the case of nisei it was more a matter of internalisation. The children of the immigrants came to agree that the majority view was the more valid one. They both identified with the Americans and internalised the norms given to them at school. Even though many of them 
had been taught the traditional customs issei had tried to keep, they wanted to be "totally American". Thanks to the internalisation, they had a base as American citizens, also mind-wise, and they felt more secure than their parents. Later on they could learn from isse $i$ the traditions the parents secretly kept. To isse $i$ the dance was a dance of tenshi, influenced by Christian angels, performed by a Japanese Goddess. It was a dance of surrender and victory, it was harmonizing, a goal in itself. To nisei it became a means for a new goal: to spread God's kingdom on earth. They chose conversion instead of compliance: something more indirect, since they realized how a minority can influence a majority. With the dance they got in touch with Americans and tried to convince them that their views were valid. It has been said that the consistency of the argument is the most important factor, and who in post-war Hawai'i did, and does, not want peace? (cf. Hayes 1993: 49-50).

Ōgamisama's dance is supposed to be spontaneous and a dance of joy, but I have seen many men marching around like soldiers, aggressively, while they are listening to the taped sermons of the foundress. She shouts and seems to enjoy freaking out. "Having cried out vehemently in this way, Ōgamisama closed the grand public sermon by saying, 'Hawai'' is an important place from which, as a foothold, the Divine Doctrine is to be introduced to the world. Therefore, no error or misunderstanding of the doctrine will be tolerated" (Tensho-kotai-jingu-kyo 1954: 179). The peace dance is shaped in a form of blind discipline, demanding unquestioning obedience. Out in the parks, among tourists and so-called Caucasians, aggressiveness became offensiveness, go-ahead-and-catch, make a good score, proselytize. There was overhanging requests in an imperative mood. Dance as a carrier of an aggressive approach, born in a wild dance performed by a frustrated and frantic woman, an instrument to recruit adherents: is that the dance of the Dancing Religion? At least it was one dance. One of them.

It was also a revolutionary dance. The frantic woman acted like a man, that is why the people she met thought she was strange. Kitamura Sayo dressed in men's clothes, rode a bicycle (no women in Japan did that in the 1940s), spoke like a man, and acted aggressively - something that was only allowed for men. In other words, she overstepped the limits of what was permissible, and she madly enjoyed being angry. When she died in 1967, it was because her high blood pressure became too high. 


\section{Conclusion}

After a fire in July 1942 a spirit entered the body of a farmer's wife in the Yamaguchi prefecture in Japan. The woman, Kitamura Sayo, did not lose consciousness of her own identity but had a conversation with the deity inside, who communicated with her and ordered her around. If she did not obey, she became ill; therefore she took cold baths of penance six times a day with prayer. The only way to unite with God was through purifying one's mind and polishing one's soul. This was done by means of a magic formula na-my $\bar{o}-h \bar{o}-r e n-g e-k y \bar{o}$ and an "ego-less" dance called muga-no-mai.

After Kitamura Sayo began to receive inspiration from a deity, "the day came when Her life as the wife of Seinoshin Kitamur ended, and Her life as a Saviour gradually began. At the same time She began to forget about Her only son Yoshito, who was at the front during World War II". In the same text about "Ogamisama: The Saviour" we can read: "LieutenantGeneral Fuji, with whom Ogamisama was acquainted, once said 'If She had been born a male, She would now be a man of the highest rank, a premier or a general"' (Ogamisama 1968: 27-28).

We have here a woman filled with aggressiveness depending on different types of aggressive motivation: inter-male (not unusual in females), sexrelated, maternal, danger-induced, and irritable. Possessed, she dressed like a man and started acting like one. She became a threat to men in positions of leadership, as a charismatic leader and "revealer" of so called truths. She turned dominance hierarchies upside down and she interfered in territorial fights. The family farm was successful and if the phenomenon of territoriality is a way to limit and structure inter-male aggression, she was involved in defending the space against intruders in a way that looked like warfare. Among animals inter-male aggression is sex-related in the sense that the establishment of high rank leads to opportunities to mate. In Kitamura Sayo's case it meant the opposite. As an usurper, she used her powerful position inside the family to refuse having sex. So her sex-related aggression is probably more a response to frustration. When it comes to maternal aggression, a mother will attack anything that threatens her child, and that is what Japan did. The nation, in Kitamura Sayo's eyes: the emperor, took her son away (during the war she did not know if he was dead or alive).

It seems like the dancing goddess felt attacked by the barn fire, the possessive element in her body, her neighbours and surroundings, as well as politicians and the nation as a whole. 
A move on the part of someone who is being attacked might well be to offer an appeasement gesture. Sometimes the dance of Kitamura Sayo is aggressive and militaristic, and sometimes it is done in a pleasing way, even though she is aroused and upset. Self-defence aggression involves sympathetic nervous system arousal, as a response to an attack, and so does irritable aggression. "Perhaps being in an aversive state gives rise to ideas associated with violence through a process of association" (Sabini 1992: 496), because after her dances Kitamura Sayo screamed like a maniac and scolded everyone. "God uses me as His Mouthpiece to reprimand people severely and directly... I went to Hawai'i 14 years ago to teach the people. My sermons are the same today, but they sound differently to the people there who have gradually become true human beings by practicing my teaching in their daily lives. When I visited Hawai'i last year, I did not scold the people as severely as I did during my first visit" (Ogamisama's Sermon 1966: 9).

Did the coffee farmers in Hawai'i accept being yelled at by God's messenger? Yes. They were losers, and Kitamura Sayo told them how bad they were. "There is enough evidence that the foundress successfully manipulated her follower's guilt and shame as if she were aware of the dialectic interdependence between self-blame and faith in salvation. She inflated and deflated the follower's feelings of shame and guilt in such a way that drastic relief from self-blame could be attained" (Lebra 1970: 52).

Even if frustration per se does not neccessarily instigate aggression, the degree to which one is frustrated can affect the degree to which one becomes angry. The workers were frustrated and angry. They had been transgressed against and felt illigitimately frustrated. The bombing of Pearl Harbor involved on their behalf unjustified frustration. Perhaps anger is turned on when someone perceives frustration as unjustified. When Kitamura Sayo scolded them and told them how worthless they were, they agreed with her and converted to her teaching. Through a ritualized marching-around-dance the male converts could canalize the emotions and "act out", regardless of whether that kind of aggressivness would remove the frustration or not. The women frequently used old bon-dance steps during muga-no-mai. ${ }^{2}$ Among the women the dance was relaxed and not military like.

\footnotetext{
${ }^{2}$ In Japan, the urabon festival has been held annually since 657. It is usually held from the 13th to the 15th of the 7th month and it is a service for the repose of the dead. Popularly the festival is called bon or o-bon and it includes dancing. According to the legend, Buddha's disciple Maudgalyāyana saved his mother from suffering in the realm of hungry spirits by making offerings in accordance with some advice from Buddha.
} 
Since there was a general tendency among the Japanese to somatize illness, most of the people that joined the Dancing Religion had complaints that were physical. Stereotypically seen, being Japanese, when you are annoyed you do not talk about it. "It is often more important to communicate through attitude, action, and feeling than through words... This kind of behavior in its extreme form may indeed occur in a Japanese as a kind of 'acting out' behavior which is radically different from violent, explosive, or disruptive behavior observed in a Western patient", according to Hawai'ian medical journals (Rogers and Izutsu 1980: 97).

Perhaps it is necessary here to make a distinction between aggressive reactions and aggressive tendencies. Through controlling the released tendency with a ritualized and somewhat institutionalized "dancingbehaviour" the members are not acting aggressively. They let Kitamura Sayo arouse them with her insults and aggressiveness, but when they dance they do not think about themselves. The dancers try to be "ego-less", to reach an altered state of consciousness through repeating na-my $\bar{o}-h \bar{o}-$ ren-ge-kyō in a monotone. There are both emotional and instrumental components involved. As a group "patternized" in the same Procrustean bed, I think we can leave individual factors aside. Inside this specific group they interpret the ritual situation with Kitamura Sayo (before alive, now on tape) in very much the same way, and they act in a similar way in the same situation. Therefore this is a form of aggressiveness that is suppressed and turned into repentance. It can be traced to the outer conditions in the specific situation that triggered off aggressive tendencies, but it was forbidden feelings. The converts should ask their divine leader to be forgiven, since aggressiveness could produce evil spirits. The situation during a dancing ritual was always ambivalent. In public places it was different. When the members of the Dancing Religion were dancing with Kitamura Sayo, it was a matter of situational factors. The instrumental aggression that was shown when they danced in public could have been a product of their knowledge about the consequences of aggressive behaviour. On the pattern of Kitamura Sayo, taking her as a model, they knew that it is possible to make friends by being aggressive, and it is possible to make peace

When she was saved, she danced out of happiness, and so did Maudgalyāyana with the spirit of his mother. Bon dance is when the living are supposed to dance in the middle of the summer together with the spirits of the dead. Besides the popular legend about the Avalambana sūtra and its contents, there are serious ethymological research on the bon concept made by Stephen F. Teiser in Teiser 1988 
in the world through an aggressive "ego-less" dance, as a means to proselytize ignorant people and make them realize that only through making a Japanese religion a world religion can there be peace on earth. It was aggressiveness as a drama set up by the dancing goddess, an act called proselytism.

A functionalistic explanation of the dance among Japanese plantation workers in Hawai'i who were members of the Dancing Religion is that aggressiveness in this case had a function. And this function explains the aggressiveness. Through aggressive cues the members could increase the tendency to proselytize aggressively because of their associations with aggressive behaviour. Making the dancing ritual as good as possible was catching as many people as possible of those that become curious about the dance. Of course, there is no purpose or cause flitting along that can explain the aggressivity inside different members. If I could explain it by telling you that there is a consciously created instituition, made especially for aggressiveness, then it would not be a functionalistic explanation, but a teleological. "Our understanding of aggression, as well as our experience of it, is literally polytextual. Altough by our social conventions about explanation we tend to opt for singular stories at a given moment, we are nevertheless at some level aware that we use more than one story... All facts about aggression, all research findings, are inevitably contingent and located" (Rogers et al. 1995: 171).

In a historical framework the dance is aggressive, the real dance acts out frustration. The ideal dance is harmony itself, always there, neither becoming, nor disappearing. In post-war Hawai'i, in an "ego-less" state, the dancers danced the ideal dance, the dance of angels, in between the marches. The dance that was observed by anthropologists in parks was real and aggressive. The natural world, the world in the ordinary sense of the word, was constantly there for them, as long as they looked in its direction. At the natural standpoint some researchers had another way of stating the same thing as I do, in my ideal worlds-about-me. The natural world is, of course, present to me, and I am at the natural standpoint as well as they are. But $I$ interpret it as a background for my consciousness, as act. The dance I describe to you is a dance experienced and visualized with a little help from my reference frame. It is both real and ideal, depending on how I look at it. An aggressive dance for harmony. A war-coloured peace-dance. "The two worlds are present together but disconnected, apart, that is, from their relation to the Ego, in virtue of which I can freely direct my glance or my acts to the one or to the other" (Husserl 1962: 94). 


\section{References Cited}

Brinson, Peter

1988 Epilogue: Anthropology and the Study of Dance. In: Paul Spencer (ed.), Society and the Dance. The Social Anthropology of Process and Performance; pp. 206-214. Cambridge: Cambridge University Press. [1985]

Buss, A. R.

1966 Instrumentality of Aggression, Feedback and Frustration as Determinants of Physical Aggression. Journal of Personality and Social Psychology 3: 153-162.

Edwards, John

1989 Language, Society and Identity. Oxford: Basil Blackwell. [1985]

Hayes, Nicky

1993 Principles of Social Psychology. Hove: Lawrence Erlbaum.

Hodgens, Pauline

1988 Interpreting the Dance. In: Janet Adshead (ed.), Dance Analysis. Theory and Practice; pp. 60-89. London: Dance Books.

\section{Husserl, Edmund}

1962 Ideas: General Introduction to Pure Phenomenology. London: Macmillan.

Kerner, Karen

1979 Building God's Kingdom: Society and Order in a Japanese Utopian Community. New York. [unpubl. thesis, Columbia University]

Kimura, Yukiko

1992 Issei. Japanese Immigrants in Hawaii. Honolulu: University of Haw aii Press. [1988]

Lebra, Takie Sugiyama

1967 An Interpretation of Religious Conversion: A Millennial Movement among Japanese-Americans in Haw aii. [unpubl. thesis, University of Pittsburg]

1970 Logic of Salvation: The Case of a Japanese Sect in Hawaii. The International Journal of Social Psychiatry 16/1: 45-53.

1972 Acculturation Dilemma: The Function of Japanese Moral Values for Americanization. Council on Anthropology and Education Newsletter 3/1: 6-13.

Lewis, I. $M$.

1989 Religion in Context. Cults and Charisma. Cambridge: Cambridge University Press. [1986]

Loew, C. A.

1967 Acquisition of a Hostile Attitude and its Relationship to Aggressive Behaviour. Journal of Personality and Social Psychology 5: 335-341.

Matsuno, Jonko

1972 Other Religious Organizations, 1 Japanese Religion: A Survey, by the Agency for Cultural Affairs; pp. 225-232. Tokyo: Kodansha International. 


\section{Moloney, James Clark}

1954 Understanding the Japanese Mind. New York: Philosophical Library.

Ogamisama

1968 Ogamisama: The Saviour. Voice from Heaven 5/26: 24-28.

Ogamisama's Sermon

1966 Ogamisama's Sermon. Voice from Heaven $3 / 16$.

1986 Ogamisama's Sermon. Voice from Heaven 133.

Rogers, Rex Stanton et al.

1995 Social Psychology. A Critcal Agenda. Cambridge: Polity Press.

Rogers, Terence A., and Saturu Izutsu

1980 The Japanese. In: John F. McDermott, Wen-Shing Tseng, and Thomas W. Maretzki (eds.), People and Cultures of Hawaii. A Psychocultural Profile; pp.73-99. Honolulu: University Press of Hawaii.

Sabini, John

1992 Social Psychology. New York: Norton.

Teiser, Stephen F.

1988 The Ghost Festival in Medieval China. Princeton: Princeton University Press.

Tensho-kotai-jingu-kyo

1954 The Prophet of Tabuse. Tabuse: Tensho-kotai-jingu-kyo.

1960 Key to Heaven. A Concise Explanation of God's Teaching. Tabuse: Tensho-kotai-jingu-kyo.

Turner, Victor

1990 Dramas, Fields, and Methaphors. Symbolic Action in Human Society. Ithaca: Cornell University Press. [1974] 